\begin{tabular}{cc|c}
\hline Tar. Bil. Der. & Tarım Bilimleri Dergisi & Journal of Agricultural Sciences \\
& $\begin{array}{c}\text { Dergi web sayfası: } \\
\text { www.agri.ankara.edu.tr/dergi }\end{array}$ & Journal homepage: \\
& www.agri.ankara.edu.tr/journal
\end{tabular}

\title{
In vitro Symbiotic Culture Studies of Some Orchid Species
}

\author{
Arzu ÇIĞ $\breve{a}^{\mathrm{a}}$, Hüdai YILMAZ ${ }^{\mathrm{b}}$ \\ ${ }^{a}$ Siirt University, Agriculture Faculty, Department of Horticulture, Kezer Campus, Siirt, TURKEY \\ ${ }^{\boldsymbol{b}}$ Pamukkale University, School of Applied Sciences, Denizli, TURKEY
}

\section{ARTICLE INFO}

Research Article DOI: 10.15832/ankutbd.385859

Corresponding Author: Arzu ÇÎj ,E-mail: arzucig@yahoo.com, Tel: +90 (531) 6231533

Received: 27 August 2014, Received in Revised Form: 19 February 2016, Accepted: 16 September 2017

\begin{abstract}
This study investigated the formation of protocorms and shoots from in vitro cultured seeds of Dactylorhiza iberica (Bieb. ex Willd.) Soó, D. umbrosa (Kar. and Kir.) Nevski, and Orchis palustris Jacquin. Culture conditions included binucleate Rhizoctonia and Rhizoctonia solani isolates, which were symbiotic cultures isolated from the tubers of these plants, and culture media consisting of an oat medium (OM) or a modified oat medium (MOM). The shortest times for protocorm and shoot development of $D$. umbrosa sowed in OM were 42.67 and 66 days, respectively. The highest rate of protocorm development and the lowest percentage of formation of darkened protocorms in D. umbrosa were $60 \%$ (in $\mathrm{OM}$ ) and $2.99 \%$ (in MOM), respectively. The maximum percentage of shoots obtained from protocorms was $35.04 \%$ for D. iberica cultured in OM. All data were obtained using binucleate Rhizoctonia sp. inoculates in the nutrient media. Keywords: In vitro; Orchid; Protocorm; Rhizoctonia spp.; Shoot
\end{abstract}

\section{Bazı Orkide Türlerinin in vitro Simbiyotik Kültür Çalışmaları}

\section{ESER BİLGİSI}

Araştırma Makalesi

Sorumlu Yazar: Arzu ÇIĞ, E-posta: arzucig@yahoo.com, Tel: +90 (531) 6231533

Geliş Tarihi: 27 Ağustos 2014, Düzeltmelerin Gelişi: 19 Şubat 2016, Kabul: 16 Eylül 2017

\section{ÖZET}

Bu çalı̧̧mada Dactylorhiza iberica (Bieb. ex Willd.) Soó, Dactylorhiza umbrosa (Kar. et. Kir.) Soó ve Orchis palustris Jacquin türlerine ait in vitro kültüre alınmış tohumlardan protokorm ve sürgün oluşumları incelenmiştir. Simbiyotik kültürler, bitkilerin yumrularından izole edilen binükleik Rhizoctonia ve Rhizoctonia solani izolatları ile yulaf ortamı (YO) ve modifiye yulaf ortamından (MYO) oluşmaktadır. Protokorm ve sürgün oluşumunda en erken süre, sırasıyla, 42.67 gün ve 66 gün olarak YO’na ekilmiş olan D. umbrosa türünde belirlenmiştir. En yüksek protokorm gelişim ve en az kararan protokorm oluşum oranı sırasıyla \% 60 oranında (YO) ve \% 2.99 oranında (MYO) D. umbrosa türünden elde edilmiştir. Protokormlardan elde edilen sürgünler, en fazla YO'da gelişen D. iberica türünde \% 35.04 olarak tespit edilmiştir. Tüm veriler, besi ortamlarında, binükleik Rhizoctonia izolatının kullanılması ile elde edilmiştir.

Anahtar Kelimeler: In vitro; Orkide; Protokorm; Rhizoctonia spp.; Sürgün 


\section{Introduction}

Orchid seeds are among the smallest seeds of all flowering plants because they lack endosperm and the embryo is not developed (Mitchell 1989). Orchid seeds therefore have extremely limited proliferative capacity and require suitable growing conditions (e.g., temperature, light, humidity, and oxygen), as well as the ability to establish appropriate associations with mycorrhizal fungi at the sites where they fall from the parent plant (Sezik 1984). Lacking nutrient reserves means that successful orchid seed germination cannot be realized without an external carbohydrate source such as glucose (Ingold \& Hudson 1993). All the orchids are therefore obligate mycorrhizal plants and their associations are mostly with Rhizoctonia sp. This association is not species-specific, which means that different orchid species can be infected by the same species of Rhizoctonia (Andersen \& Rasmussen 1996). A successful attempt to obtain rootlets in the symbiotic culture of Coelogyne nervosa seeds, an epiphytic orchid species, and Epulorhiza sp. isolate obtained from the Eulophia epidendrea root, a terrestrial orchid, indicates that the relationship between orchids and fungus is not species-specific (Sathiyadash et al 2014).

Orchid mycorrhiza can sometimes be described as parasitic due to the attacks of fungi and protocorms (Burges 1939). An infection attempt might be prevented by the plant if the seedling has a strong defense reaction (Garrett 1981; Hudson 1986). Researchers have also reported that only a certain number of the orchids in an appropriate habitat germinate when they encounter Rhizoctonia species; a seedling might be infected and might even die if the inoculums potential of the fungus is high. Paradoxically, fungal isolates have different impacts on different species; they can support or hinder plant survival. This emphasizes the importance of studying the survival and propagation capabilities of orchid species under natural or aseptic conditions, as their germination and development is heavily dependent on ambient conditions. Symbiotic in vitro seed germination in the examination of orchid with experimental and protection purpose, is seen as one of the popular tools (Stewart et al 2003; Swarts \& Dixon 2009). Related to this, increasing number of symbiotic protocols was prepared for terrestrial orchids around the world (Fracchia et al 2014).

In this study, the protocorm and shoot development stages were examined for some terrestrial orchids started as seedlings using Rhizoctonia sp. isolated from their tubers as an in vitro symbiotic culture medium.

\section{Material and Methods}

\subsection{Orchid source}

In the study, the seeds and tubers of Dactylorhiza iberica (Bieb. ex Willd.) Soó, Dactylorhiza umbrosa (Kar. et Kir.) Soó, and Orchis palustris (Jacquin) species were used. The plants were collected from the meadows of the Edremit and Erciş Districts of Van Province between July and August when the capsules were brown. The seeds were kept at $+4{ }^{\circ} \mathrm{C}$ temperature and in the dark until it is used.

\subsection{Fungal isolation}

The fungus was isolated from tubers washed with tap water and sterilized for 3 minutes in 3\% commercial sodium hypochlorite $(\mathrm{NaOCl})$ solution in a sterilized cabin. Tuber explants, $0.5 \times 0.5 \mathrm{~cm}$ in size, were sown in three different commercial media [water agar, potato dextrose agar (PDA), and yeast extract agar (YEA)] and incubated for 3-4 days at $24^{\circ} \mathrm{C}$. After mycorrhizal hyphae on the media were detected by light microscopy, Mycelia were purified and kept in glass tubes containing PDA at $+4{ }^{\circ} \mathrm{C}$ temperature and in the dark.

\subsection{Fungal species identification}

Test isolates used to determine anastomosis groups are supplied from the collections of the Department of Plant Protection at Faculty of Agriculture, Yüzüncü Y1l University. The origins of test isolate were different plants and they were molecularly identified. After the isolates obtained from the plants and test isolates were developed in PDA at $25 \pm 2{ }^{\circ} \mathrm{C}$ for 7 days, it was matched in $1.5 \%$ of water agar. With this aim, mycelium disks taken with cork 
drillers $(5 \mathrm{~mm})$ from the isolate obtained from the plant with test isolate were placed at a distance of 2-4 $\mathrm{cm}$ reciprocally; the line that hyphae after incubation at $25 \pm 2{ }^{\circ} \mathrm{C}$ for $48-72$ hours was dyed with lactophenol consisting of $0.5 \%$ trypan and it was examined directly in optical microscope in order to identify whether there was a unification status of cell wall and cytoplasmic among hyphae (Parmeter et al 1969).

\subsection{Symbiotic culture medium}

Oat medium $(\mathrm{OM})$ as symbiotic culture (rolled oats 2.5 g L ${ }^{-1}$, agar 0.7\%, pH 5.7) (Clements \& Ellyard 1979) and modified oat medium (MOM), $\left(\mathrm{Ca}\left(\mathrm{NO}_{3}\right)_{2} \cdot 4 \mathrm{H}_{2} \mathrm{O}\right.$ $0.2 \mathrm{~g} \mathrm{~L}^{-1}, \mathrm{KH}_{2} \mathrm{PO}_{4} \cdot 7 \mathrm{H}_{2} \mathrm{O} 0.2 \mathrm{~g} \mathrm{~L}^{-1}, \mathrm{MgSO}_{4} \cdot 7 \mathrm{H}_{2} \mathrm{O} 0.1$ $\mathrm{g} \mathrm{L}^{-1}, \mathrm{KCl} 0.1 \mathrm{~g} \mathrm{~L}^{-1}, \mathrm{MgSO}_{4} \cdot 7 \mathrm{H}_{2} \mathrm{O} 0.1 \mathrm{~g} \mathrm{~L}^{-1}$, yeast extract $0.1 \mathrm{~g} \mathrm{~L}^{-1}$, rolled oats $3.5 \mathrm{~g} \mathrm{~L}^{-1}$, agar $0.6 \%$, pH 5.7) (Clements et al 1986) were used. Medium up to $20 \mathrm{ml}$ was poured into glass petri dishes. Seven-dayfungal isolates were inoculated as disks in the size of $0.5 \times 0.5 \mathrm{~cm}$ on one side of culture media.

\subsection{Seed sowing}

The orchid seeds were sterilized by shaking in $2 \%$ sulfuric acid for 5 minutes, followed by a 12-minute treatment with 1-2 drops of Tween-20 and $10 \% \mathrm{NaOCl}$, and three rinses for a few minutes in sterilized water. The study was conducted in 3 replicates for each treatment. In each replicate, 6 pieces of petri were used; there were 100 pieces of seeds in each petri dishes. The seeds were sowed on the other side of petri dish where fungal isolate was placed. The culture was kept at $23 \pm 1{ }^{\circ} \mathrm{C}$ temperature and in the dark until the first protocorm was seen. After the first protocorm was formed, it was kept in climate chamber providing light/dark photoperiod for 16/8 hours. For the protocorm and shoot formation, sub-cultures were made to the jars containing the corresponding cultural medium where the seeds were sowed once a month.

\subsection{Statistical analysis}

The trials in which $\mathrm{R}$ is included were not statistically evaluated. Binucleate Rhizoctonia was evaluated by considering the nutrient medium and the species interaction.
In the evaluation of the data "variance analysis in factorial order in the randomized plot design" was made. The measured percentage changes were subjected to angle transformation prior to the analysis of variance. Following the analysis of variance, Duncan's multiple comparison test was used for determination of differences among the species and media. The statistical significance level was set at $(\mathrm{P}<0.05)$ and all analyses were conducted using the SPSS (ver.13) statistical package software.

\section{Results and Discussion}

\subsection{Fungal isolation}

A Rhizoctonia solani AG-3 (R) fungal isolate was successfully isolated from a tuber explant of $D$. umbrosa species cultured on water agar (Figure 1); a binucleate Rhizoctonia (2R) isolate was isolated from tubers of $O$. palustris species cultured on PDA (Figure 2). The rapid sprouting of the fungus in the nutrient medium in the petri dishes meant that germination could not be precisely defined, but protocorm and shoot formation was observed. None of the media inoculated with $R$. solani fungi resulted in any germination or protocorm formation. That the fungus isolated from the roots and tubers of orchids could not show any symbiotic effect on the seeds is a frequent situation encountered by the researchers. It is not encouraging for the species of $R$. solani isolate, Orchis italica and Serapias vomeracea (Oğuz et al 2005; Sarı et al 2011) and in Bipinnula fimbriata species (Steinfort et al 2010) since fungi have a pathogenic effect on Cattleya skinneri seeds, and since they cause the death of all seeds in a few days (Ovando et al 2005), it may be seen as an example. Some fungal isolates isolated from the tubers of Spiranthes spiralis (L.) and some fungal isolates brought from abroad did not have any symbiotic effect on the seeds of the species of D. romana subsp. romana (Sazak 2004). Despite this, in the symbiotic culture carried out with the seeds of Spiranthes sinensis var. amoena, the isolates of $R$. solani and binucleate Rhizoctonia anastomosis groups were used, and it was detected that fungi had positive effects on the germination of 
the seeds (Masuhara et al 1993). Each isolate used in the species of $S$. vomeracea subsp. laxiflora and Orchis laxiflora could not provide the same effect (Özkoç 1991). Although some isolates stimulated the germination, protocorm and plant formation, some isolates had no effect on the symbiotic culture done with Dendrobium chrysanthum and pathogenic Rhizoctonia isolates, (Hajong et al 2013).

As evidenced in the studies conducted in the expectation that fungi has a symbiotic effect, it causes death due to its pathogenic effect as well as to the fact that it enters the process of plants via seen germination and protocorm.

\subsection{Darkened protocorm ratio (\%)}

Some of the protocorms that developed in both media turned brown and soft shortly after removal, indicating a loss of viability (Figure 3). These protocorms were still counted and evaluated statistically (Table 1). Their percentages were calculated as a proportion of the total number of seeds. Examination of the presence of darkened protocorms among the D. iberica, D. umbrosa and $O$. palustris seeds sowed in $\mathrm{OM}$ and MOM revealed a statistically significant difference $(\mathrm{P}<0.05)$. The highest proportion (37.38\%) of darkened protocorms was obtained from $O$. palustris in MOM, while the lowest percentage $(2.99 \%)$ was seen in D. umbrosa in MOM, confirming a clear difference among the species. Comparison of the culture media revealed that the lowest and highest darkening ratios for $D$. umbrosa occurred in the MOM and OM, respectively, indicating a correlation between development and culture media. Similarly, the highest and the lowest darkening ratios were obtained in different species grown in the same nutrient medium (MOM), indicating a significant effect of the nutrient media on different species.

Symbiotic germination studies of Serapias vomeracea subsp. laxiflora and O. laxiflora in OM and MOM media reported the darkening of in a $5.1 \%$ of the protocorms in MOM medium 1 month


Figure 1- Rhizoctonia solani and its source, the tuber of D. umbrosa species


Figure 2- Binucleate Rhizoctonia (2R) and its source, the tuber of $O$. palustris species 




Figure 3- Darkened protocorms developed in the 2R+MOM culture medium

Table 1- The effect of the culture medium on protocorm darkening (\%) in Dactylorhiza iberica, D. umbrosa, and Orchis palustris

\begin{tabular}{llll}
\hline Mediums & Dactylorhiza iberica & Dactylorhiza umbrosa & Orchis palustris \\
\hline Oat medium & $9.31 \pm 0.27$ a* C** & $26.43 \pm 0.26$ a A & $15.57 \pm 0.35 \mathrm{~b} \mathrm{~B}$ \\
Modified oat medium & $8.71 \pm 0.25 \mathrm{a} \mathrm{B}$ & $2.99 \pm 0.11 \mathrm{~b} \mathrm{C}$ & $37.38 \pm 0.56 \mathrm{a} A$ \\
\hline
\end{tabular}

*, in the same column, lower case letters indicate a none significant difference between the averages at the 0.05 level; **, in the same row, upper case letters indicate a none significant difference between the averages at the 0.05 level

after planting(Özkoç 1991). A similar darkening and rotting after germination was observed for the seeds of D. osmanica var. osmanica sown in OM with R. solani (Sazak \& Ozdener 2006). Some researchers mentioned that gradual darkening and protocorm putrefaction might be observed in culture studies including fungi and extending more than 16 weeks at $20{ }^{\circ} \mathrm{C}$ (Shimura \& Koda 2005).

In our study, the $2 \mathrm{R}$ isolate stimulated protocorm development, however, it also promoted a substantial protocorm darkening. The darkened protocorms lose their vitality and do not send out shoots, so a darkened protocorm can be interpreted as a loss of the shoot and the plant. The $2 \mathrm{R}$ isolate had the strongest influence on $O$. palustris in MOM medium. The fungal isolate obtained from the tuber was thought to possibly have a parasitic effect on the seeds of the same species under appropriate conditions.

\subsection{Total protocorm ratio (\%)}

The total protocorm number was evaluated as the combined total numbers of robust and darkening protocorms and ratios were calculated by dividing the protocorm numbers by the total number of seeds. The differences observed for total protocorm formation among $D$. iberica, D. umbrosa, and $O$. palustris sown in OM and MOM were statistically significant $(\mathrm{P}<0.05)$ (Table 2$)$. The highest ratio was obtained for D. umbrosa in OM, as $60.74 \%$, and the lowest ratio was obtained for $D$. iberica in OM, at 9.45\% (Figure 4). In the other nutrient media, the highest ratio was also obtained from $D$. umbrosa; the lowest ratio was obtained from $D$. iberica.

Table 2- The effect of the culture medium on the total number of protocorms (\%) developed in Dactylorhiza iberica, D. umbrosa, and Orchis palustris

\begin{tabular}{llll}
\hline Mediums & Dactylorhiza iberica & Dactylorhiza umbrosa & Orchis palustris \\
\hline Oat medium & $12.98 \pm 0.38 \mathrm{a}^{*} \mathrm{C}^{* *}$ & $60.74 \pm 0.54 \mathrm{a} \mathrm{A}$ & $25.95 \pm 0.29 \mathrm{~b} \mathrm{~B}$ \\
Modified oat medium & $9.45 \pm 0.81 \mathrm{~b} \mathrm{C}$ & $56.74 \pm 0.30 \mathrm{~b} \mathrm{~A}$ & $41.84 \pm 0.39 \mathrm{a} \mathrm{B}$ \\
\hline
\end{tabular}

*, in the same column, lower case letters indicate a none significant difference between the averages at the 0.05 level; **, in the same row, upper case letters indicate a none significant difference between the averages at the 0.05 level 




Figure 4- D. umbrosa protocorms in $2 \mathrm{R}+\mathrm{MOM}$ culture medium

The highest protocorm development was $2.35 \%$ for D. iberica seeds cultured in OM with mycorrhizal fungi isolates and $4.72 \%$ when cultured in MOM (Özdener 1994). For D. aristata the highest protocorm development was $45.10 \%$ when cultured in OM (Hayakawa et al 1999). In a study the highest protocorm development rate was $22.1 \%$ in OM and $3.3 \%$ in MOM for S. vomeracea, whereas the rate was $4.8 \%$ for $O$. laxiflora cultured in $\mathrm{OM}$ and $5.2 \%$ when cultured in MOM (Özkoç 1991). In agreement with the present study, the highest and the most positive results in these studies were generally obtained with OM. In a study inoculated with binucleate Rhizoctonia and $R$. solani isolate, in $O$. palustris and $S$. vomeracea subsp. vomeracea species, protocorm formation was seen in a previous study (Esitken et al 2005). In symbiotic study conducted in OM with Spiranthes brevilabris Lindley seeds, Epulorhiza repens become successful among 4 fungal isolates. The first protocorms were emerged around 7-8\% after 10-12 weeks of the culture (Stewart \& Kane 2007). In OM conducted between fungal isolates isolated from the species of Disa bracteata and 6 orchid species; $14-90 \%$ protocorms were obtained in the species of
Caladenia falcata and Pterostylis sanguinea. In this study, it is understood that entophytic orchids can be germinated with fungus but the protocorm formation is due to the physiological imbalance of the fungi (Bonnardeaux et al 2007). The seeds of Pecteilis susannae increased the protocorm formation with Epulorhiza isolate over 60\% (Chutima et al 2011).

As it is mentioned above, the highest and positive results, consisted with the previous studies, were obtained from $\mathrm{OM}$ to a great extent. These results can be interpreted that nutrient mediums have important effects on protocorm formation. Similarly, fungi cause protocorm formation in media that may be regarded as low in some species where they may behave different from orchid species while higher level of formation was obtained in some species.

\subsection{Ratio of shoots obtained from protocorms (\%)}

The shoot ratio was expressed as the percentage of developed shoots to the total number of protocorms, regardless of whether the protocorms were darkened. The differences between the average numbers of protocorms and shoot formation were statistically significant $(\mathrm{P}<0.05)$ (Table 3).

Table 3- The effect of the culture medium on shoot formation (\%) from the protocorms of Dactylorhiza iberica, D. umbrosa, and Orchis palustris

\begin{tabular}{llll}
\hline Mediums & Dactylorhiza iberica & Dactylorhiza umbrosa & Orchis palustris \\
\hline Oat medium & $35.04 \pm 1.12 \mathrm{a}^{*} \mathrm{~A} * *$ & $18.00 \pm 0.51 \mathrm{~b} \mathrm{~B}$ & $15.56 \pm 0.17 \mathrm{a} \mathrm{B}$ \\
Modified oat medium & $14.28 \pm 0.58 \mathrm{~b} \mathrm{~B}$ & $32.59 \pm 1.00 \mathrm{a} A$ & $7.77 \pm 0.59 \mathrm{~b} \mathrm{C}$ \\
\hline
\end{tabular}

*, in the same column, lower case letters indicate a none significant difference between the averages at the 0.05 level; **, in the same row, upper case letters indicate a none significant difference between the averages at the 0.05 level 
The highest mean values belonging to shoot formation were obtained in the ratio of $35.04 \%$ in the species of $D$. iberica in OM; however these shoots were not developed as healthy as in other species; they continued their lives as short and weak (Figure 5). The lowest shoot formation was found to be $7.77 \%$ from the species of $O$. palustris in MOM. The shoot was obtained from the protocorms formed approximately at the rates of $7-35 \%$ in our study.

Shoot formation failure is frequently observed in the protocorms developing from symbiotically germinated seeds (Hayakawa et al 1999). A study carried with nine fungal isolates reported the highest shoot formation in D. urvilleana as $55.80 \%$ in OM and $60.60 \%$ in MOM; while the highest rate for D. iberica was $3.10 \%$ in $\mathrm{OM}$ and $4.80 \%$ in MOM (Özdener 1994). Further experiments using six different nutrient media, prepared by modifying MOM, gave results that varied from no shoot formation to as much as $1.20 \%$ shoot formation. Symbiotic germination studies with $S$. vomeracea and $O$. laxiflora reported the highest shoot formation of $14.3 \%$ and $2.8 \%$ in $\mathrm{OM}$ and MOM, respectively, in $S$. vomeracea and $6.9 \%$ and $4.1 \%$, respectively, in O. laxiflora (Özkoç 1991). In this study, inoculations of BNR 8-3 mycorrhizal isolate isolated in the species of $D$. urvilleana and in the species of $O$. palustris, to which polyethylene glycol was applied in OM, the first output of the leaf has a 21\% chance of success (Esitken et al 2004).

Symbiotic germination studies of $D$. hatagirea (with YEA addition) and Ceratobasidium sp. in
OM resulted in shoot initiation in $61 \%$ of all the germinated seeds (Aggarwal \& Zettler 2010). In that study, the germinated seeds developed protocorms in 40 days. In a symbiotic study conducted in OM with binucleate Rhizoctonia and Rhizoctonia solani AG-6 isolated from the plant of Anoectochilus formosanus Hayata, both isolates increase the growth of the plants of $A$. formosanus to a great extend (Chang \& Chou 2007). In OM, the seed of Spiranthes brevilabris Lindley and Epulorhiza repens isolate indicated successful results. The first shoots were observed around $10 \%$ and $6 \%$ in $10^{\text {th }}$ and $12^{\text {th }}$ weeks of the culture, respectively, and extention of the shoots were detected around $50 \%$ and $60 \%$ in $10^{\text {th }}$ and $12^{\text {th }}$ weeks, respectively (Stewart \& Kane 2007).

\subsection{Protocorm formation time (days)}

The period between the planting of the orchid seeds in the petri dish containing the culture medium with mycorrhizal fungus and the appearance of the first protocorm was designated as the protocorm development time. The nutrient media had statistically significant effects on it $(\mathrm{P}<0.05)$ (Table 4). The shortest development time (42.67 days) was observed in D. umbrosa seeds planted in OM, while the longest time (55.33 days) was observed in O. palustris seeds planted in OM. The seeds of different species showed clearly different growth in the nutrient media and therefore had different protocorm development times. All the plant species examined had protocorm development times of approximately 2 months.

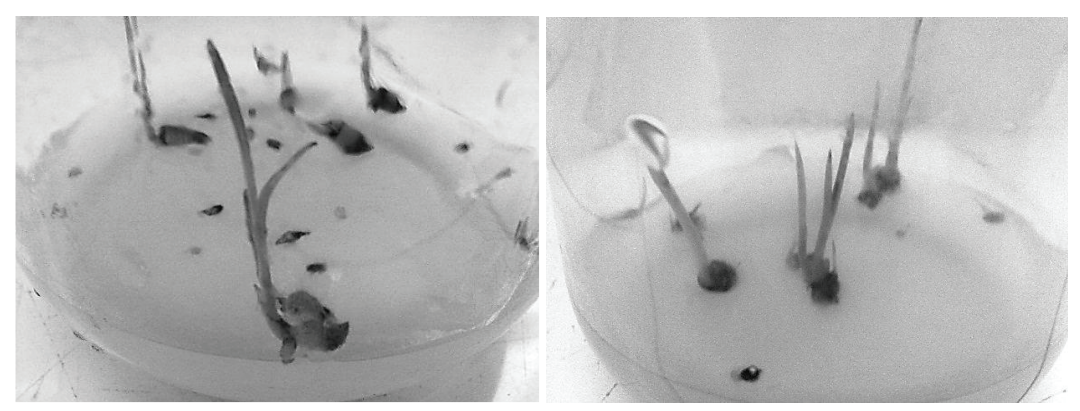

Figure 5- D. iberica shoots in $2 \mathrm{R}+\mathrm{OM}$ culture medium 
Table 4- The effect of the culture medium on the protocorm formation time (days) for Dactylorhiza iberica, D. umbrosa, and Orchis palustris

\begin{tabular}{llll}
\hline Mediums & Dactylorhiza iberica & Dactylorhiza umbrosa & Orchis palustris \\
\hline Oat medium & $48.67 \pm 0.88 \mathrm{~b}^{*} \mathrm{~B}^{* *}$ & $42.67 \pm 0.88 \mathrm{~b} \mathrm{C}$ & $55.33 \pm 0.67 \mathrm{a} \mathrm{A}$ \\
Modified oat medium & $53.00 \pm 1.15 \mathrm{a} \mathrm{A}$ & $51.67 \pm 0.88 \mathrm{a} \mathrm{AB}$ & $49.67 \pm 0.33 \mathrm{~b} \mathrm{C}$ \\
\hline
\end{tabular}

*, in the same column, lower case letters indicate a none significant difference between the averages at the 0.05 level; **, in the same row, upper case letters indicate a none significant difference between the averages at the 0.05 level

In a study, the protocorms of the species of $D$. hatagirea sowed in $\mathrm{OM}$ with fungal isolates belonging to the species of Ceratobasidium developed in 40 days (Aggarwal \& Zettler 2010). Seeds of D. maculata germinated with an $R$. stahlii isolate developed protocorms in two weeks (Beyrle et al 1985); however, the authors reported that this rapid protocorm development might have been a result of stimulation by cold treatment. Protocorm development occurred 1.5-2 months in $O$. coriophora seeds cultured in OM with $R$. solani (Vakkasoğlu 1995). The Dactylorhiza and Orchis species showed protocorm development in 40-60 days when cultured with a symbiotic fungus on either OM or MOM.

\subsection{Shoot formation time (days)}

The period between the planting of the orchid seeds in the petri dishes (containing culture medium and the mycorrhizal fungus) and the appearance of the first shoot was designated the shoot formation time. The different species showed statistically significant differences in the shoot formation time $(\mathrm{P}<0.05)$ (Table 5). The earliest and the latest shoot formation times in MOM were 63.67 days for O. palustris and 78.67 days for $D$. iberica, respectively. The timing of the initiation of shoot formation after protocorm development varied depending on the species and the medium; however, green shoot formation was rapid in all three species. This means that healthy protocorms can develop and form shoots more rapidly in the presence of symbiotic fungi. All three species formed shoots in 14-27 days after protocorm development (Table 4).

Species of the Dactylorhiza genus are reported as a difficult group of orchids to cultivate (Mitchell 1989). The results of the present study confirmed that species of the Dactylorhiza genus formed shoots later than a member of the Orchis genus did. A previous study reported that the time required for the development of green leaves in Spiranthes sinensis var. amoena, when grown in symbiotic culture in OM and various Rhizoctonia isolates, was 90 days (Masuhara \& Katsuya 1994). In a symbiotic culture between the seeds of Rhizoctonia cerealis isolate and D. maculata spp. ericetorum, green shoot growth from the protocorms began 90 days after the seed sowing (Weber \& Webster 2001). With being infected of Spathoglottis plicata seeds with Epulorhiza repens and Rhizoctonia globularis isolates, the time passed between the seed sowing and the beginning of leafing was 60 days (Athipunyakom et al 2004). In the symbiotic culture of fungal isolates obtained from the species of orchids and the seeds of Oncidium flexuosum, some isolates started to germinate but it did not contribute

Table 5- The effect of the culture medium on the shoot formation time (days) of Dactylorhiza iberica, D. umbrosa and Orchis palustris

\begin{tabular}{llll}
\hline Mediums & Dactylorhiza iberica & Dactylorhiza umbrosa & Orchis palustris \\
\hline Oat medium & $73.33 \pm 0.33 \mathrm{~b}^{*} \mathrm{~A}^{* *}$ & $66.00 \pm 1.00 \mathrm{~b} \mathrm{~B}$ & $75.67 \pm 0.88 \mathrm{a} A$ \\
Modified oat medium & $78.67 \pm 0.88 \mathrm{a} \mathrm{A}$ & $78.33 \pm 0.88 \mathrm{a} \mathrm{A}$ & $63.67 \pm 0.88 \mathrm{~b} \mathrm{~B}$ \\
\hline
\end{tabular}

*, in the same column, lower case letters indicate a none significant difference between the averages at the 0.05 level; **, in the same row, upper case letters indicate a none significant difference between the averages at the 0.05 level 
to the protocorm and plant formation at a desired level and some of them promoted leaf formation 50 days after protocorms (Pereira et al 2005). With 5 fungal isolates isolated from it, the species of $\mathrm{Aa}$ achalensis promoted 2-4 leaf formation from 30\% of the protocorms in 16 weeks after the growth (Sebastián et al 2014). The similarity between the nutrient media and fungal isolates used in these studies suggests the possibility that the observed shoot formation differences might be species specific.

\section{Conclusions}

The choice of the nutrient medium and the fungal isolate for in vitro symbiotic culture of orchid seeds has extremely important effects on germination, protocorm formation, and shoot initiation. Some fungi never promote the germination of orchid seeds, or have a very insignificant impact on orchid development, and sometimes they even have a parasitic effect. The differences observed in the present study with respect to protocorm formation from the germinated seeds sown in oat medium and modified oat medium are likely to reflect the combination of agents added to the culture medium. The data obtained from our study were detected in the cultures to which $2 \mathrm{R}$ is infected. The observation that orchid species developed more protocorms in oat medium culture indicated that this nutrient medium favored optimum growth of the binucleate Rhizoctonia symbiont enabling a better symbiosis. The differences due to the nutrient media can be explained by the different effects of a given fungal isolate on different orchid species. The more successful germination and protocorm development seen in Dactylorhiza umbrosa seeds with the binucleate Rhizoctonia isolate, obtained from an Orchis palustris tuber, supports the view of some researchers that the degree of effectiveness of fungal isolates might vary with species. The formation of darkened protocorms, which was evaluated separately in the present study, could be viewed as a loss, as these protocorms could not form shoots. The nutrient medium had a significant effect on the the total number of protocorms developed, with the highest number of protocorms seen with Dactylorhiza umbrosa and the lowest with Dactylorhiza iberica. The lowest success rate was obtained with Orchis palustris in both nutrient media. The other species showed their best performances in oat medium and modified oat medium at different levels. Protocorm development took approximately 1.5-2 months after planting in all the species and each species had a different timing in different nutrient media. Accordingly, the shoot formation times also varied. The shortest shoot and protocorm development occurred in oat medium culture. The use of oat medium and modified oat medium infected with binucleate Rhizoctonia sp. gave the least amount of protocorm darkening, the highest protocorm number, and the fastest development of protocorms in Dactylorhiza umbrosa, it gave the highest number of shoots in Dactylorhiza iberica, and it resulted in the fastest shoot formation in Orchis palustris.

\section{Acknowledgements}

This study is a part of a Doctorate Dissertation Project (2009, FBE-D036) financed by Yüzüncü Y1l University, Van, Turkey Scientific Research Projects Department.

\section{References}

Aggarwal S \& Zettler L W (2010). Reintroduction of an endangered terrestrial orchid, Dactylorhiza hatagirea (D. Don) Soo, assisted by symbiotic seed germination: First report from the Indian subcontinent. Nature and Science 8(10): 139-145

Andersen F T \& Rasmussen H N (1996). The Mycorrhizal Species Of Rhizoctonia, Rhizoctonia Species, Taxonomy, Molecular Biology, Ecology, Patology, And Disease Control (B. Sneh, S. Jabaji-Hare, S. Neate \& G. Dijst). Kluwer Academic Publishers, Dordrecht. pp. 379-390

Athipunyakom P, Manoch L, Piluek C, Artjariyasripong S \& Tragulrung S (2004). Mycorrhizal fungi from Spathoglottis plicata and the use of these fungi to germinate seeds of $S$. plicata in vitro. Kasetsart Journal (Natural Sciences) 38(1): 83-93 
Beyrle H, Pennigsfeld F \& Hock B (1985). Orchid mycorrhiza: Symbiotic propagation of the some Dactylorhiza species. Zeitscrift-fur-Mykologie 51(2): 185-198

Bonnardeaux Y, Brundrett M, Batty A, Dixon K, Koch J \& Sivasithamparam K (2007). Diversity of mycorrhizal fungi of terrestrial orchids: compatibility webs, brief encounters, lasting relationships and alien invasions. Mycological Research 111: 51-61

Burges A (1939). The defensive mechanism in orchid mycorrhizas. New Phytologist 38(3): 273-283

Chang D C-N \& Chou L-C (2007). Growth responses, enzyme activities, and component changes as influenced by Rhizoctonia orchid mycorrhiza on Anoectochilus formosanus Hayata. Botanical Studies 48: $445-451$

Chutima R, Dell B, Vessabutr S, Bussaban B \& Lumyong S (2011). Endophytic fungi from Pecteilis susannae (L.) Rafin (Orchidaceae), a threatened terrestrial orchid in Thailand. Mycorrhiza 21(3): 221-229

Clements M A \& Ellyard R K (1979). The symbiotic germination of Australian terrestrial orchids. American Orchid Societly Bulletin 48: 810-816

Clements M A, Muir H \& Cribb P J (1986). A preliminary report on the symbiotic germination of European terrestrial orchids. Kew. Bulletin 41(2): 437-445

Esitken A, Ercisli S, Eken C \& Tay D (2004). Seed priming effect on symbiotic germination and seedling development of Orchis palustris Jacq. HortScience 39(7): 1700-1701

Esitken A, Ercisli S \& Eken C (2005). Effects of mycorrhiza isolates on symbiotic germination of terrestrial orchids (Orchis palustris Jacq. and Serapias vomeracea subsp. vomeracea (Burm. f.) Briq.) in Turkey. Symbiosis 38(1): 59-68

Garrett S D (1981). Soil Fungi and Soil Fertility. $2^{\text {nd }}$. Edition, Perganon. Oxford, pp. 150

Hajong S, Kumaria S \& Tandon P (2013). Compatible fungi, suitable medium, and appropriate developmental stage essential for stable association of Dendrobium chrysanthum. Journal of Basic Microbiology 53(12): 1025-1033

Hayakawa S, Uetake Y \& Ogoshi A (1999). Identification of symbiotic Rhizoctonias from naturally occurring protocorms and roots of Dactylorhiza aristata (Orchidaceae). Journal of the Faculty of Agriculture Hokkaido University 69(2): 129-141
Hudson H J (1986). Fungal Biology. Edward Arnold, London, pp. 298

Ingold C T \& Hudson H J (1993). The Biology of Fungi, Sixth Edition (Chapman \& Hall). London, pp. 224

Masuhara G \& Katsuya K (1994). In situ and in vitro specificity between Rhizoctonia spp. and Spiranthes sinensis (Persoon) Ames. var. amoena (M. Bieberstein) Hara (Orchidaceae). New Phytologist 127(4): 711-728

Masuhara G, Katsuya K \& Yamaguchi K (1993). Potential for symbiosis of Rhizoctonia solani and binucleate Rhizoctonia with seed of Spiranthes sinensis var. amoena in vitro. Mycological Research 97(6): 746752

Mitchell R B (1989). Growing hardy orchids from seeds at Kew. The Plantsman 1: 152-169

Oğuz B, Sari A O \& Bilgiç A (2005). Ege Bölgesi'nde Yayılış Gösteren Bazı Salep Orkidelerinin Üretim Olanaklarının Araştırılması. Tagem Proje Sonuç Raporu, Proje No: Tagem/Ta/02/02/03/010

Ovando I, Damon A, Bello R, Ambrosio D, Albores V, Adriano L \& Salvador M (2005). Isolation of endophytic fungi and their mycorrhizal potential for the tropical epiphytic orchids Cattleya skinneri, $C$. aurantiaca and Brassavola nodosa. Asian Journal of Plant Sciences 4(3): 309-315

Özdener Y (1994). Dactylorhiza urvilleana (Steudel) Bauman Künkele ve Dacytlorhiza iberica (Bieb. Ex Willd) Soo (Orchidaceae) türlerinin köklerinden fungusların izole edilmesi, bu türlere ait tohumların simbiyotik ve asimbiyotik kültür ortamlarında çimlenme ve gelişmesi üzerinde bir araştırma. Doktora tezi, Ondokuz Mayıs Üniversitesi Fen Bilimleri Enstitüsü (Basılmamış), Samsun

Özkoç İ (1991). Serapias vomeracea (Burmfil.) Briq. Sub sp. laxiflora (Soo) Gölz et. Reinhard ve Orchis laxiflora Lam. (Orchidacea) tohumlarının simbiyotik ve asimbiyotik kültürlerde çimlenme ve gelişmesi üzerinde araştırılması. Doktora tezi, Ondokuz Mayıs Üniversitesi Fen Bilimleri Enstitüsü (Basılmamış), Samsun

Parmeter J R, Sherwood R T \& Platt W D (1969). Anastomosis grouping among isolates of Thanatephorus cucumeris. Phytopathology 59(9): 1270-1278

Pereira O L, Kasuya M C M, Rollemberg C \& Borges A C (2005). In vitro symbiotic seed germination of Oncidium flexuosum (Orchidaceae) by Rhizoctonia- 
like mycorrhizal fungi. Revista Brasileira de Ciência do Solo 29(2): 199-206

Sari A O, Tutar M \& Çiçek F (2011). Ege Tarımsal Araştırma Enstitüsü salep üretim çalışmaları. I. Salep Orkidesi Çalıştayı, 24-25 Mayıs, Kahramanmaraş, s. $65-86$

Sathiyadash K, Muthukumar T, Murugan S B, Sathishkumar R \& Pandey R R (2014). In vitro symbiotic seed germination of South Indian endemic orchid Coelogyne nervosa. Mycoscience 55(3): 183189

Sazak A (2004). Bazı orkide türlerine ait tohumların simbiyotik ve asimbiyotik olarak çimlendirilmesi ve fide gelişimi. Yüksek lisans tezi, Ondokuz Mayıs Üniversitesi Fen Bilimleri Enstitüsü (Basılmamış), Samsun

Sazak A \& Ozdener Y (2006). Symbiotic and asymbiotic germination of endangered Spiranthes spiralis (L.) Chevall. and Dactylorhiza osmanica (K1.) Soó var. osmanica (endemic). Pakistan Journal of Biological Sciences 9(12): 2222-2228

Sebastián F, Vanesa S, Eduardo F, Graciela, T \& Silvana $S$ (2014). Symbiotic seed germination and protocorm development of Aa achalensis Schltr., a terrestrial orchid endemic from Argentina. Mycorrhiza 24(1): $35-43$

Sezik E (1984). Orkidelerimiz, Türkiye'nin Orkideleri. Sandoz Kültür Yayınları. No: 6, s. 166
Shimura H \& Koda Y (2005). Enhanced symbiotic seed germination of Cypripedium macranthos var. rebunese following inoculation after cold treatment. Physiologia Plantarum 123(3): 281-287

Steinfort U, Verdugo G, Besoain X \& Cisternas M A (2010). Mycorrhizal association and symbiotic germination of the terrestrial orchid Bipinnula fimbriata (Poepp.) Johnst (Orchidaceae). FloraMorphology, Distribution, Functional Ecology of Plants 205(12): 811-817

Stewart S L \& Kane M E (2007). Symbiotic seed germination and evidence for in vitro mycobiont specificity in Spiranthes brevilabris (Orchidaceae) and its implications for species-level conservation. In Vitro Cellular \& Developmental Biology-Plant 43(3): 178-186

Stewart S L, Zettler L W, Minso J \& Brown P M (2003). Symbiotic germination and reintroduction of Spiranthes brevilabris Lindley, an endangered orchid native to Florida. Selbyana 24(1): 64-70

Swarts N D \& Dixon K W (2009). Terrestrial orchid conservation in the age of extinction. Annals of Botany 104(3): 543-556

Vakkasoğlu F (1995). Orkidelerde mikorizal fungusların orkide tohumlarının çimlenmesi ve büyümeleri üzerine etkisi. Yüksek lisans tezi, Çukurova Üniversitesi Fen Bilimleri Enstitüsü (Basılmamış), Adana

Weber R W S \& Webster J (2001). Teaching techniques for mycology: 14. Mycorrhizal infection of orchid seedlings in the laboratory. Mycologist 15(2): 55-59 